\title{
The Rise of the Lord's Resistance Army: HIV/AIDS or Politics?
}

\author{
Cons Matata ${ }^{1}$ \\ ${ }^{I}$ Hekima University College, Institute of Peace Studies and International Relations, Nairobi, Kenya
}

\begin{abstract}
The war in northern Uganda, between the Lord's Resistance Army (LRA) and the central government which is generally agreed to have started in 1986 and ended in 2006, has attracted many theories as to its origin. While most scholars blame it on marginalisation, discrimination, loss of power by the locals and religious fanaticism which led to acts of terrorism, we assert that one of the underlying causes or perhaps the only leading cause was the emergence of "slim' or HIV/AIDS. The other so-called causes could have only been mere triggers of the desperation stemming from this disease which at the time had no known medical relief, unlike today when we have a plethora of medicines which can be applied to its management and to prolong life. The influx of the Ugandan National Resistance Army which led to the setting up of barracks and garrisons in nearly all parts of Acholiland, the setting up of the Local Defence Unit which considerably increased the number of armed personnel in the region as well as forcing people into over-crowded internally displaced camps with little amenities and privacy further exacerbated the spread of HIV/AIDS and in turn public opinion against the National Resistance Movement/Army (NRM/A) government.
\end{abstract}

Key words: HIV/AIDS, LRA, marginalisation, NRM/A, power

The rise of the Lord's Resistance Army, at best, has been enigmatic. This is due to several reasons. The first reason has to do with the fact that from the colonial times until 1986 the Acholi nation dominated the armed forces. This too had its explanation. The colonial governments, be it British, French, Portuguese or the Spanish, preferred to use outlying territories and people for labour reserves such as the Luo, Kamba and Abaluyha peoples in Kenya or the people who lived in the southern part of Sudan in the former Sudan; and now the Republic of South Sudan. The Acholi nation being some $340 \mathrm{~km}$ from the capital was therefore considered "outlying" or far and thus was used as a labour reserve for the sugar, coffee and tea plantations around the capital Kampala and the industrial town of Jinja as well as in the armed forces. These were the occupations that required little or no education. Unlike the people closer to the capital such as the Baganda, the Basoga, etc, who were the pioneer candidates in mission and government schools, formal education did not reach the Acholi nation until about 1915. In contrast, many schools were already up and running in the central province. Missionaries of all categories (Catholics, Protestants, Hindus, Muslims, etc.) also preferred to work closer to the capital where roads, healthcare facilities, security and other amenities were available.

On the other hand the introduction of poll tax or tax payable by every able-bodied male of which nonpayment attracted heavy jail terms meant that the choice was both the tedious cultivation and sale of cotton [1] or migrating to the central province for salaried jobs. The majority of the young and able bodied, particularly men, in the outlying regions opted for travelling long distances to either Kampala or Jinja in search of jobs. Thus, at independence the Acholi nation dominated the jobs that "required only braw rather than brain." In fact the Ugandan armed forces became known as a profession for those with minimal or no education. Further, Kiswahili being the dominant language used in the armed forces meant that there was no need to go to school to learn English, as Kiswahili, unlike English, could easily be learnt informally. Thus soldiering became part of the Acholi life [2].

Consequently, at independence, the Acholi nation dominated the armed forces. When Amin overthrew Obote's regime in 1971, he had to bring his own supporters into the army. This meant purging the majority Acholi. Many Acholi officers were killed, jailed or fled into exile [3]. When Obote was reinstated into power in 1980, the Acholi resumed their dominant position in the armed forces. The Acholi in Obote's government later on overthrew his government in 1985. However, their victory was short lived as Museveni overthrew them in 1986. Many scholars therefore trace the rise of Lord's Resistance Army to these events or more specifically to the defeat of Okellos army by the Museveni led National Resistance Army in 1986 [4, 5, 6, 7]. Some scholars even give the timeline of the conflict as from 1986 to 2006 [4], [8]. This conflict led to destruction of the social fabric in northern Uganda and was characterised by poor and unhygienic living conditions in internally displaced camps and the extreme poverty that came with such living [9] or as Lauer [10] puts it:"In 1986 the Lord's Resistance Army (LRA) began an intrusive rebellion in Northern Uganda against Yoweri Museveni's new central state. For the last nineteen years the LRA has disrupted the everyday life of 40,000 village children who are obliged to sleep away from home, on hospital floors and verandas of other public buildings in the larger 
towns, to avoid kidnap after dark by marauding LRA guerrillas (BBC World Service News, May 13, 2005). Since the mid-1980s, 95 percent of the population in the three northern districts have been forced to migrate, and 1.8 million out of the nation's total 24.7 million now live in refugee camps, where sanitary and nutritional conditions are substandard. In a thirteen month period during 2002-2003, as many as 10,000 children were abducted by the LRA for actual armed conflict and for auxiliary sexual and housekeeping services"

On the other hand some scholars attribute the rise of this movement to "religious terrorism or fanaticism leading to terrorism" [11] or purely religious reasons [12]. When looked at purely from the above angles, grievance, fanaticism and terrorism become the main factors in the rise of the Lord's Resistance Movement; after all the Acholiland was indeed marginalised. However, Kigezi and Karamoja did not fare any better in terms of marginalisation yet did not take up arms against the central government. Therefore, the grievance, religious fanaticism or extremism leading to terrorism narrative alone ignores other underlying factors that could have given rise or substantially contributed to the emergence of the Lord's Resistance Movement. Perhaps then, the most singular contributor to the rise of the LRA is HIV/AIDS. Although Twesigye [13] attributes the rise of another religious movement in western Uganda (the Movement for the Restoration of the Ten Commandments), to HIV/AIDS, the same can also be applied to the case of LRA. To conclude that: “... aspects of the Acholi insurgency in Northern Uganda have been initiated and led by spirit mediums, notably Alice Auma and Joseph Kony. Because Kony's career as an insurgent leader has been marked by atrocity and the lack of an explicit political programme, he has often been dismissed as a terrorist. It is argued here that he at least deserves the status of 'social bandit' as defined by Hobsbawm, and that his role as a voice for spirit messages is still a significant factor. It is concluded that without recognition of the role of spirit messages in African conflicts these conflicts will be imperfectly understood and their resolution will be correspondingly more problematic" [12], completely misses the point. It is like merely treating the symptom rather than the cause.

HIV/AIDS was identified among heterosexual Ugandans in 1982 [14, 15, 16]. This was after it was identified among homosexuals in the USA in 1981 [17]. Before it was scientifically identified, it was known as "slim" in Uganda due to its victims' severe loss of weight before death [18]. According to Serwadda [18] at the time of its discovery there was no treatment or remedies for what he describes as "a new disease in Uganda and its association with HTLV-III infection." The emergence of HIV/AIDS coincided with Museveni's National Resistance Movement armies invading Acholiland to mop up the remnants of the Tito Lotuwa Okello-Basilio Okello forces [19]. To make the matter worse, many of the Okello forces had merged with the local population with their weapons. Rape, robbery, murder and other vices became common. The large numbers of the victors' and the vanquished armies in the area with barracks, both formal and informal, which were being set up by the victors further contributed to the breakdown of the moral fabric. This was further compounded by the fact that the men were mostly in hiding and therefore women received little support from their men in terms of food cultivation, emotional support and other basic necessities and yet the victors came with money and military rations such as tinned beef, biscuits, whiskies, etc. This led to an explosion of prostitution on an unimaginable level and with it an explosion in the number of victims of "slim" [20]. Further, the Acholi people had always associated the armed forces with loose living or prostitution. The military barracks were considered, since the Anglo-Nubian conquest of Acholiland, as the symbols of prostitution [21]. To add salt to injury, the National Resistance Army later on started what they called Local Defence Unit (LDU) composed mainly of locals who agreed, or were forced to join the government army or saw joining the government army as a better opportunity for survival. This in effect brought distrust between the LRA fighters and the civilians as according to Olsen [7]:

"Thus, in a peculiar way the LRA has justified the killings of civilians by arguing that civilians have given up their civilian status by cooperating with the army. The government strategy of establishing civilian self-defence units in Acholiland (which was initiated around 1990) was particularly important in fostering this perception among LRA fighters and contributed greatly to legitimising attacks on civilians. In the eyes of the LRA leadership the formation of the self-defence units served as a final proof that the Acholi civilian society could no longer be trusted and that they should therefore be treated as part of the enemy force".

Apart from fostering the enmity among the locals, the creation of the Local Defence Unit or LDU also meant that the loose living associated with the army and its attendant spread of HIV/AIDS, was now devolved to the local level. Historically, a vicious religious campaign by the Italian Verona (now Comboni) missionaries in the late $20^{\text {th }}$ century meant that the Acholi region became predominantly Catholic with its equally dominant Marian ideology [22]. It did not take long after the outbreak of "slim" before these Catholic Marians realized that sin and "slim" were conjoined twins [23]. To banish the deadly "slim" one had to discard sin as well. Alice Lakwena, whose family were ardent Catholics, soon identified Catholic Christian rituals and beliefs that could be performed to purge both the body and soul from this sin which ultimately led to "slim". These were the rosary, the Ten Commandments and other rituals such as the anointment with oil. Alice soon found out that the recitation of some beads of the rosary over a "slim" infected person brought them some relief [3]. Patients therefore flocked to her from all corners of Uganda and as far as the Congo, Sudan, Rwanda, Burundi, Kenya and Tanzania since, according to Fisher [24] in his "The Bizarre and Horrifying Story of the Lord's Resistance 
Army "The story of the Lord's Resistance Army begins with a madwoman from the village of Opit in northern Uganda. After 30 years of uneventful life, Alica Auma disappeared into a nature reserve for several weeks. When she emerged, she said she had been possessed by an Italian army officer whom she called Lakwena, which means "word of God." For about a year, Alice Lakwena, as she was now known, worked as a healer and oracle. Then, one day, she announced that Lakwena had a new plan for her. She would purify first her native lands in northern Uganda, and then the world, through combat. War would be a divine form of healing, she said, in which those that die are like rotten flesh cut out by a surgeon, and in which the pure could not be killed". The choice of an "Italian army officer" was not an accident as nearly all members of the Verona missionaries at the time were Italians. Alice achieved her feat through performance of the exaggerated versions of the Catholic rituals. In addition to performing such acts like saying the rosary over her desperate patients, Alice also called for the adherence to the Ten Commandments to avoid future infections. Who could disagree with her since the commandments called for among others abstention from adultery and other acts of immorality? [3]. It was music to the ears of the patients and their relatives. Slim was spreading fast. It was no longer confined to the prostitutes and the armed forces. Among its new victims were clerical officers, lawyers, teachers, nurses, politicians, etc. Some of them went to Alice for a cure. Alice's call for the establishment of the rule of the Ten Commandments in the entire country while being welcomed by some was totally opposed by the government. To the government such a call meant being accountable or being overthrown. The government had to act to stem Alice's call from gaining mass support. However, the government's reaction was a little too late. Politicians had already noticed the mobilising ability in Alice's movement. It did not take long for the politicians in Alice's camp to start calling for the overthrow of the "oppressive, corrupt and evil government" [25] of Yoweri Museveni. In short the politicians had taken over the LRA movement and had turned it into their weapon against the government. What had started as a religious movement against HIV/AIDS or "slim" had now become a political revolution ready to confront the government. The availability of Tito Lotuwa Okello-Basilio Okello's forces that had fled with their weapons meant that there were ready forces only too willing to settle scores with the government's regular army. Alice's newly acquired attributes as a prophetess who could cure AIDS with the rosary and anointment with oil, also brought in much needed morale into the fighters. The prophetess could make them immune to death through bullets [3] in the same way that she had brought an end to death from "slim".

\section{REFERENCES}

[1] Ahmed, M., \& Ojangole, S. (2012). Analysis of incentives and disincentives for cotton in Uganda.. Rome: FAO.

[2] ] Veale, A., \& Stavrou, A. (undated). IssaAfrica. Retrieved from issaafrica.org: https://www.issafrica.org/uploads/Mono92.pdf

[3] Behrend, H. (1999). Alice Lakwena and the Holy Spirits: War in Northern Uganda, 1985-1997. Oxford, Kampala, Nairobi and Athens, Ohio: James Currey, Fountain Publishers, EAEP and Ohio University Press.

[4] Dolan, C. (2009). Social Torture: The Case of Northern Uganda 1986-2006. New York: Berghahn Books.

[5] Sensitivity, A. C. (2013). Northern Uganda: Conflict Analysis. London and Kampala: Advisory Consortium on Conflict Sensitivity.

[6] Dolan, C. (2007). Uganda Strategic Conflict Analysis. Stocklohm: Sida.

[7] Olsen, K. T. (2007). VIOLENCE AGAINST CIVILIANS IN CIVIL WAR UNDERSTANDING ATROCITIES BY THE LORD'S RESISTANCE ARMY IN NORTHERN UGANDA. Ghent University: Conflict Research Group.

[8] Durick, H. E. (2013). University of Tennesee Honors Thesis Projects. Retrieved from trace.tennesee: http://trace.tennessee.edu/cgi/viewcontent.cgi?article=2625\&context=utk_chanhonoproj

[9] Muhwezi, W. W., Kinyanda, E., Mungherera, M., Onyango, P., Ngabirano, E., Muron, J., . . Kajungu, R. (2011, October 19). Vulnerability to high risk sexual behaviour (HRSB) following exposure to war trauma as seen in post-conflict communities in eastern uganda: a qualitative study. Conflict and Health, 5(22). doi:10.1186/1752-1505-5-22

[10] Lauer, H. (2006). Cashing in on Shame:How the Popular "Tradition vs.Modernity" Dualism Contributes to the "HIV/AIDS Crisis" in Africa. Review of Radical Political Economics, 90-138.

[11] Kanyamurwa, J. M. (2016). Assessment of Policy and Institutional Approaches to International Terrorism in Uganda. M i d d l e E a s t R e vi e w o f P u b li c A d min i s t r a t i o n, 2(1). Retrieved July 6, 2016, from file:///C:/Users/JERSEY/Downloads/assessment_of_policy_and_institutional_approaches_to_internation al_terrorism_in_uganda.pdf

[12] Sturges, P. (2011). The Role of Spirit Messages in African Conflicts the Case of Joseph Kony and the Lord's Resistance Army in Uganda. The Open Information Science Journal, 76-79. 
[13] Twesigye, E. K., Aden, S., \& Benedicts, M. W. (2005). THE ETHICS OF HIV/AIDS AND THE RISE OF AN APOCALYPTIC MARIOLOGIST MOVEMENT FOR THE RESTORATION OF THE TEN COMMANDMENTS . Scriptura89, 456-458.

[14] Amutuhaire, W. (Undated). HIV in Uganda-Makerere University News Portal. Retrieved from https://news.mak.ac.ug/documents/aw/HIVinUg.ppt

[15] Tumishabe, J. (2006). The Politics of HIV/AIDS in Uganda. Geneva: United Nations Research Institute for Social Development.

[16] Okware, S., Opio, A., Musinguzi, J., \& Waibale, P. (2001). Fighting HIV/AIDS: is success possible? Bulletin of the World Health Organization, 1113-1120.

[17] Control, C. f. (2001, June 1). Morbidity and Mortality Weekly First Report of AIDS. (T. F. Rutledge, Ed.) Centre for Disease Control Journal, 50(21), 429-456. Retrieved July 6, 2016, from http://www.cdc.gov/mmwr/pdf/wk/mm5021.pdf

[18] D.Serwadda; N.K. Sewankambo; J.W. Carswell; A.C. Bayley; R.S. Tedder; R.A. Weiss; R.D. Mugerwa; A. Lwegaba; G.B.Kirya; R.G. Downing; S.A. Clayden; A.G. Dalgleish. (1985, October 19). The Lancet, 326(8460), 849-852. doi: http://dx.doi.org/10.1016/S0140-6736(85)90122-9

[19] Council, N. R. (2004). PROFILE OF INTERNAL DISPLACEMENT :UGANDA. Geneva: Norwegian Refugee Council.

[20] Branch, A. (2008). GULU TOWN IN WAR... AND PEACE? DISPLACEMENT, HUMANITARIANISM AND POS TWAR CRISIS. Columbia University, Department of Political Science . London: Crisis State Research Centre. Retrieved July 6, 2016, from http://wwwrohan.sdsu.edu/ abranch/Publications/Gulu\%20Town\%20in\%20War...and\%20Peace--Branch.pdf

[21] Amone, C. (2014, April). A History of Prostitution in Acholi-Land, Northern Uganda, 1911 to 2011. IJSR - INTERNATIONAL JOURNAL OF SCIENTIFIC RESEARCH, 3(4). Retrieved July 8, 2016, from http://www.worldwidejournals.com/international-journal-of-scientific-research(IJSR)/file.php?val=April_2014_1396529282_c3770_168.pdf

[22] Nthamburi, Z. (Ed.). (1991). From Mission to Church: A Handbook of Christianity in East Africa. Nairobi: Uzima Press.

[23] Sophia Mukasa Monico, E. O., \& Nuwagaba, A. (2001). Uganda :HIV and AIDS-related Discrimination, Stigmatization and Denial . London: UNAIDS.

[24] Fisher, M. (2011, October 17). The bizarre and horrifying story of the Lord's Resistance Army. The Atlantic.

[25] Twesigye, E. K. (2010). Religion, politics and cults in East Africa:God's warriors and Mary's saints. New York: Peter Lang Publishing Inc. 